\title{
Firm Investments and Corporate Governance in Asian Emerging Markets
}

\author{
Tanweer Hasan \\ Roosevelt University, U.S.A. \\ Palani-Rajan Kadapakkam \\ University of Texas at San Antonio, U.S.A. \\ P. C. Kumar \\ American University, U.S.A.
}

The quality of corporate governance has been shown to have wide-ranging implications, e.g., on the performance of stock markets and on exchange rates. This study investigates whether the quality of corporate governance in a country impacts investment decisions made at the micro level of the firm. The study focuses on Asian emerging markets since they have widely varying standards of corporate governance. Based on eight measures of corporate governance, four aggregate indices of corporate governance (business environment, legal environment, investor rights, and an overall measure) are developed for seven countries in the sample drawing on data from published sources. The results indicate that improvements in corporate governance mitigate the dependency of firm investments on their internal resources and facilitate access by firms to capital markets (JEL: G15, G30, G31).

Keywords: corporate governance, firm investments, emerging markets, investment-cashflow sensitivity.

\section{Introduction}

Potential expropriation of investors is the outcome of the classic managerial agency problem that arises from the separation of ownership and control in the corporate form of organization. Agency conflicts between managers and investors are mitigated by legal contracts

* The authors thank the Managing Editor and an anonymous referee for valuable suggestions which improved the quality of the study. They thank James Hackard for editorial assistance and participants in a research seminar at Kogod School of Business and in the Multinational Finance Society Annual Conference, 2002, for useful comments.

(Multinational Finance Journal, 2008, vol. 12, no. 1/2, pp. 21-44)

Quarterly publication of the Multinational Finance Society, a nonprofit corporation.

(C) Global Business Publications. All rights reserved.

DOI: $10.17578 / 12-1 / 2-2$ 
embodying a set of rights that protects suppliers of capital to the firm. However, an environment in which these rights may be enforced is essential to protect investors. Such an environment is characterized by high standards of corporate governance. The presence (or absence) of corporate governance has wide-ranging effects. Johnson et al. (2000) report that measures of corporate governance explain a greater portion of the variation in exchange rates and stock market performance during the Asian crises than do macroeconomic variables. This study extends the scope of corporate governance climate in an economy by examining its impact at the micro level, specifically, on a firm's capital investment decisions.

The ability of firms to undertake profitable investments may be limited by available internal capital, since various factors may impede their access to external capital. Such impediments include transaction costs, potential for information asymmetry between insiders and outsiders, and the agency conflict between outside investors and managers. This study examines whether the presence (absence) of high quality corporate governance standards serves to control (exacerbate) agency conflicts, and, consequently, mitigate (tighten) external financing constraints on corporate investments.

The sample of corporations analyzed is drawn from seven Pacific Rim emerging economies-Hong Kong, Indonesia, Korea, Malaysia, Singapore, Taiwan and Thailand. ${ }^{1}$ The corporate governance climate in these countries is assessed from several perspectives. Measures of corporate governance for each country are obtained from information in published sources on specific elements such as judicial efficiency, corruption, transparency, investor rights, and other components. These elements are used to develop three indices of corporate governance relating to business environment, legal environment, and investor rights; finally, these indices are aggregated to yield an overall index of corporate governance.

With a view to assessing the impact of the corporate governance climate on firm investments, for each emerging market a common model is estimated linking corporate investments to measures of internal liquidity and profitability. Internal resources in Indonesia and Malaysia positively determine firm investments; while in the other countries in the sample, firm investments are determined jointly by internal resources and market factors. The determinants of firm investments are

1. Hong Kong and Singapore do not conform strictly to International Finance Corporation's definition of "emerging markets." 
estimated using pooled country data including variables interacting with measures of corporate governance specific to each country. Results suggest that improved corporate governance in a country diminishes the reliance of firm investments on its internal resources. Furthermore, the influence of the firm's investment opportunities on its investments is enhanced by improved corporate governance.

The findings of this study have broad implications. Since the 1980s, developing nations and Eastern European countries in transition have liberalized their economies and turned to market-oriented decision systems. Financial sector development is an intrinsic element of their strategy to promote economic growth. Beck, Levine and Loayza (2000) note that financial development has three different impacts on economic growth: increased savings, intermediation of these savings into real investments, and efficient allocation of resources into productive investments. Countries that protect shareholder rights experience enhanced firm valuation, increase in the number of listed firms, and growth in IPOs (LaPorta et al.[2000]). Effective protection of minority shareholders can lead to the development of broad financial markets, dispersed ownership of shares and efficient allocation of capital across firms. Thus, economies in transition and intermediate-level economies would benefit from improving their corporate governance environments.

The rest of this paper is organized as follows. Section II discusses the factors affecting firm investments, specifically, financing constraints which result in firms relying on their internal resources to finance their investments, impediments to firms accessing capital markets, and how good corporate governance practices may mitigate such impediments. Section III examines measures of corporate governance and develops an index of corporate governance for the countries in our sample drawing on previous work by LaPorta et al. $(1997,1998)$. A description of the empirical design and the data is contained in section IV. Section V presents the results of the empirical analysis. Section VI presents the conclusions from the study.

\section{Background and Research Propositions}

This study integrates two separate strands of literature-corporate governance and investment constraints on the firm. The objective of this study is to examine whether quality of corporate governance impacts the link between internal resources and corporate investment. Several diversified themes characterize the literature on corporate investments. 
The ability of firms to undertake profitable investments may be limited by available internal capital, since firms' access to external capital may be impeded by various factors. This section provides first a brief overview of the empirical evidence on the link between corporate investments and internal resources and then points out the impediments to firms obtaining external capital. The subsequent discussion examines the role of corporate governance in facilitating access to external capital in emerging markets.

\section{A. Internal Resources and Firm Investment}

Extensive earlier work has documented a positive relationship between internal cash flow and firm investment, after controlling for the profitability of investment opportunities, typically measured by Tobin's $q$. In a perfect world with free access to external capital, if a model for investments includes both Tobin's $q$ and internal cash flow, $q$ should be the only influencing variable, and the impact of cash flow should be insignificant. The finding of a positive, significant coefficient for the internal cash flow variable has been interpreted to be an indication of external financing constraints.

In the first study of this issue, Fazzari, Hubbard and Petersen (1988) use the dividend payout ratio as a proxy variable for unobservable external financing constraints. The underlying intuition is that firms treat dividend payments as the outcome of a passive residual policy, i.e., the payments of dividends are subordinated to investment opportunities; thus, the firm's dividend payout ratio is a good indicator of available surplus internal funds. Financially constrained firms are identified by their low dividend payouts, whereas high dividend paying firms are not similarly restricted. Fazzari, Hubbard and Petersen (1988) report that the investment-cash flow sensitivity is higher for low dividend payout firms compared to high dividend payout firms. ${ }^{2}$

The positive relationship between corporate investment and internal cash flow has been documented for a number of economies. For example,

2. Kaplan and Zingales (1997) re-examine the low dividend payout firms in the Fazzari, Hubbard and Petersen (1988) sample to fine-tune the classification of firms into constrained and unconstrained categories by objective criteria drawn from $10-\mathrm{K}$ reports. They find that firms with true financial constraints (as per their definition) do not necessarily have low dividend payout levels and vice-versa as assumed by Fazzari, Hubbard and Petersen (1988). More importantly, contrary to the Fazzari, Hubbard and Petersen (1988) results, Kaplan and Zingales (1997)find that financially constrained firms exhibit lower cash flow-investment sensitivity. They conclude by issuing a general caution about the use of the investment-cash flow coefficient as an indicator of financial constraint. 
Fazzari, Hubbard and Petersen (1988) and Vogt (1994) examine the issue in the context of firms in the U.S.A.; Schaller (1993) considers a group of Canadian firms; Athey and Laumas (1994) direct their study toward Indian firms; Hoshi, Kashyap and Scharfstein (1991) study Japanese firms and the impact of keiretsu relationships; and Devereux and Chiantarelli (1990) investigate the issue for U.K. corporations. Kadapakkam, Kumar and Riddick (1998) examine the issue for six OECD countries-Canada, France, Germany, Japan, U.K. and U.S.A. Based on the prior literature, this study examines the following proposition in the context of our sample of Asian emerging markets.

Research proposition 1: Corporate investment is positively related to internal cash flow and growth opportunities.

\section{B. Corporate Governance and the Corporate Investment-Internal Cash Flow Relationship}

This sub-section discusses impediments faced by firms in accessing external capital markets and describes how such constraints may be alleviated by good corporate governance policies. Finally, it follows up with a description of capital investments in emerging markets.

\section{Impediments to Firms' Access to External Capital Markets}

The significant impact of internal liquidity on corporate investment indicates that firms may have difficulty in accessing external capital markets. Transaction costs involved in raising external capital, which raise the hurdle rate for acceptable investments, are obvious sources of friction. A second possible source of friction is the potential for information asymmetry between insiders and outsiders. The seminal work of Myers and Majluf (1984) has generated considerable research on this aspect. New security issues by firms are viewed with skepticism by investors and are greeted with a negative stock price reaction which diminishes a firm's appetite for external capital. These factors should be less important for mature firms in an economy compared to young firms. Mature firms enjoy the benefit of economies of scale as well as lower information asymmetry due to a longer track record and better analyst following.

A third source of friction affecting access to external capital, and consequently investment, is the agency conflict between managers and outside investors, which has attracted considerable attention in the 
literature. The separation of ownership and control vitiates managers' attempts to solicit outside funds for investment in their firm, since outsiders are concerned about potential expropriation of the firm's resources by managers (Jensen and Meckling [1976]). Thus, firms may be restricted by the availability of internal funds in pursuing investment opportunities.

At first glance, an analysis of the link between insider ownership and corporate investment may seem the obvious way to study the impact of agency conflicts on corporate investments due to limitations on raising capital. However, the impact of insider ownership on corporate investment and firm value is ambiguous. While increases in managerial ownership lead to better alignment of managerial and stockholder interests, they can also lead to managerial entrenchment. ${ }^{3}$ Furthermore, Demsetz and Lehn (1985) argue that ownership structure may be determined endogenously in an equilibrium relation. Managers are observed to prefer equity compensation when their firm performance is expected to improve with consequent increases in corporate values. This preference results in ownership structure being determined endogenously by corporate value instead of corporate value being determined by ownership structure. Thus, this possibility leads to a circular relation among ownership, corporate investment, and firm value (Cho [1998]).

Corporate Governance and the Firm Investment-Internal Resources Nexus

The corporate governance environment is an exogenous factor influencing agency conflicts, which in turn impact the firm's access to external capital. The separation of ownership and control in the corporate form of organization gives room for managerial opportunism, resulting in expropriation of investors' funds or misallocation of corporate resources. To guard against such opportunism, investors demand a set of rights embodied in legal contracts in exchange for their resources. Debt holders are offered a series of interest payments with a priority claim on the income stream of the firm over other suppliers of capital. But in the event of default on these payments, debt holders will enforce the right to obtain possession of any collateral offered. Equity shareholders are residual claimants on the income stream and assets of the firm and, in exchange for this status, they accept the entitlement to vote on the appointment of the directors and on other decisions in the

3. Empirical analyses reveal that the relation between ownership structure and corporate value is non-monotonic (Morck, Shleifer and Vishny [1988] and McConnell and Servaes [1990]). 
firm. These contracts confer on investors the rights, and thus the means, to protect their investments in the corporation. LaPorta et al. (1998) imply that these rights form a set of necessary, but not sufficient, conditions. What is needed additionally is the legal environment in which these investor rights may be enforced. LaPorta et al. (1997) conclude that countries with poor investor protection, characterized by the nature of the governing rules and the manner in which they are enforced, have shallow capital markets.

Johnson et al. (2000) examine whether weaknesses of legal institutions in enforcing corporate governance principles were responsible for the exchange-rate depreciation and stock market declines in emerging market countries during the recent Asian financial crisis. The authors argue that a decline in the expected returns on investments (say, as a result of a combination of some exogenous factors), together with increases in managerial expropriation, would result in a reduction of local and foreign investors' confidence. The resulting increases in capital outflows and declines in capital inflows lead to exchange rate depreciation and decreases in stock market values. The authors report that corporate governance variables explain a greater proportion of the variation in exchange rates and stock market performance during the Asian crisis than do macroeconomic variables. They conclude that countries with weak corporate governance traditions (particularly, inadequately enforced minority shareholder rights) are more prone to economic fluctuations. ${ }^{4}$

\section{Corporate Investments in Emerging Markets}

Two principal motivations guide this study. In the first place, it is generally accepted that emerging markets are relatively inefficient as compared to the major markets in developed countries (Errunza [2001]). This fact, coupled with the natural impediments to accessing external capital markets (discussed earlier), limits corporate investments even further. Second, this study posits that the quality of corporate governance and legal systems in the economy in which the firm operates

4. Karmin (2000) also attributes the poor performances of emerging markets to inadequate standards of corporate governance "the equitable treatment of minority shareholders and the timely and accurate disclosure of information." The author reports that there is substantial resistance to reforming the corporate governance climate in Russia, Korea, Brazil and Poland. It is expected that reforms will be adopted in these countries when it is recognized that companies with good corporate governance practices are better insulated against market downturns. 
impacts the link between internal resources and corporate investment. Good corporate governance environments provide appropriate incentives for investors to supply capital and, thus, reduce the firm's dependency on internal resources. The degree of observance of corporate governance principles varies across countries and is manifested, inter alia, in differential legal protections offered to investors. Firms should find it easier to obtain adequate financing for their investments directly from market sources in countries with strong corporate governance traditions. The dependence of a firm's investments on its liquid assets should be less in such countries compared to that in countries with weaker corporate governance traditions, where investors would be concerned about expropriation or misallocation of corporate resources through over/under-investment. Capital markets may not be a good source for funding investments in such economies, and investments would be constrained by the availability of liquid resources within the firm. It follows that corporate investment being limited by the availability of liquid resources in emerging markets is only a symptom of a more serious underlying problem, namely, the absence of a good corporate governance environment. The impact of corporate governance regimes on corporate investments is studied by examining the following proposition.

Research proposition 2: A good corporate governance regime mitigates the dependence of corporate investment on internal cash flow.

The analysis uses data from seven Pacific Rim countries-Hong Kong, Indonesia, Korea, Malaysia, Singapore, Taiwan and Thailandsince they have very close economic ties but provide interesting variations in their legal environments. While Hong Kong and Singapore have been known to have free market economies, it has been argued that inefficient economic systems in the other countries triggered the Asian financial crisis (Johnson et al. [2000]). The next section develops measures of the effectiveness of corporate governance in these countries.

\section{Corporate Governance Measures for Asian Markets}

Table 1 presents eight separate elements of corporate governance based on published data for the seven countries included in this study. These elements include judicial efficiency, an indicator of official corruption, rule of law, enforceable minority shareholder rights, anti-director rights, 


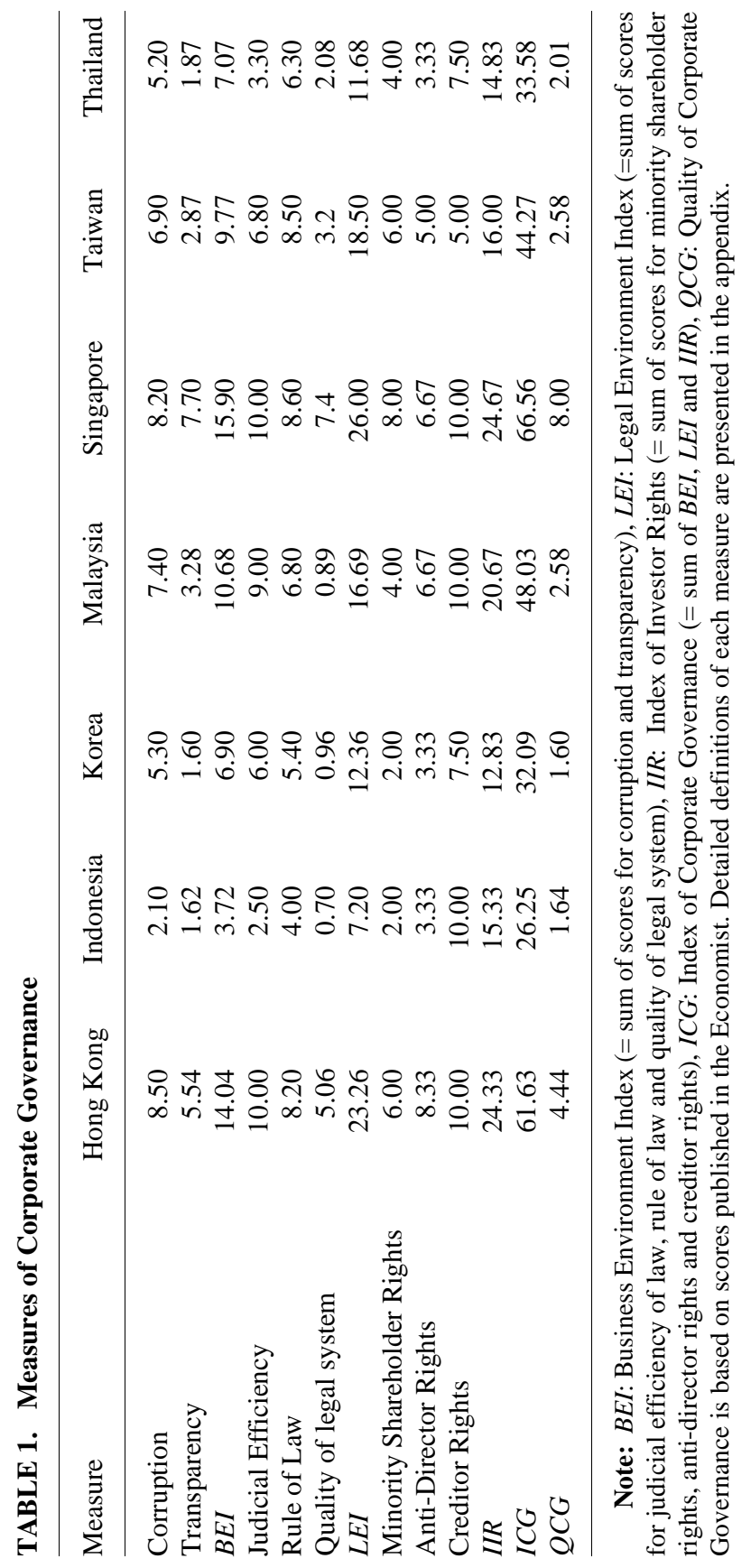


and creditor rights. Johnson et al. (2000) is the source for scores on minority shareholder rights and scores for the other measures have been extracted from LaPorta et al. (1998). The score for each element is directly related to its level of quality in the country, i.e., a high score is an indicator of high quality. These measures are supplemented by two additional measures, namely, transparency, and the quality of the legal system, published in The Economist (4.7.01).

From the eight elements of corporate governance, three indices are created relating to corporate governance for each country. The value of the first index $(B E I)$, which relates to the quality of the business environment, is obtained by aggregating the scores for corruption and transparency. Corruption is the consequence of vesting discretionary power in public officials to grant benefits or to impose costs on the private sector. It manifests eventually as an implicit tax on consumers and investors. Opacity or lack of transparency in business transactions promotes corruption. Thus, both corruption and transparency are included in the descriptors of the business environment.

The second index relates to the quality of the legal environment (LEI) and its value is obtained by aggregating scores of judicial efficiency, rule of law, and quality of the legal system. Rule of law implies a fundamental respect for the law and an agreement among all participants that the same set of rules will govern the actions of all individuals. Judicial efficiency refers to the enforcement of laws uniformly among all participants and the expeditious disposition of legal disputes. Quality of the legal system relates to the inherent fairness of laws and their enforcement. The three measures are not mutually exclusive and there is some degree of overlap or commonality among them.

The third index refers to the rights and privileges that the legal system confers on investors participating in financial markets $(I I R)$. These rights flow from the recognition of property rights to assets and the relative priority of claims on the firm's financial flows by its various stakeholders, i.e., employees, creditors and shareholders. The legal system creates and enforces laws defining rights and liabilities of corporations as well as those of their officers and directors. This index is constructed by aggregating the values for enforceable minority shareholder rights, creditor rights, and anti-director rights. While the elements of these three indices are not entirely independent of each other, it should be noted that investor rights are the product of a particular legal system being superimposed on a given business environment.

Finally, an overall index of corporate governance $(I C G)$ is created 
by aggregating the values of the eight elements that separately combined to yield the three indices, i.e., BEI, LEI, and IIR. The quality of corporate governance $(Q C G)$ (Economist, 4.7.01) is also used as an alternative overall measure.

The historical tradition underlying the legal code in each country is also considered. Following LaPorta et al. (1998), Hong Kong, Malaysia, Singapore, and Thailand are placed in the English common law category; Indonesia in the French civil law group; and Korea and Taiwan in the German civil law family. The mean ICG scores suggest that the overall corporate governance environment is best in the English common law category (52.45), followed by the German civil law family (38.18), and then in the French civil law group (26.25). This ranking is supported by the mean scores for quality of corporate governance $(Q C G)$ for the three legal families, 4.26, 2.09, and 1.64, respectively. These findings support the assertion in LaPorta et al. (1998) that countries belonging to the common law category offer the best investor protection, followed by countries in the German civil law family, and ending with Indonesia which follows French civil law.

\section{Empirical Design and Description of the Data}

The foregoing discussion forms the basis for two discrete hypotheses. The first hypothesis describes the determinants of corporate investments for each separate emerging market. The second hypothesis considers the influence of country-specific corporate governance factors on firm-level corporate investments jointly in all emerging markets.

\section{A. Corporate Investment in each Emerging Market}

The analysis examines the relationship of corporate investment $\left(I_{i t}\right)$ to internal resources $(I R E S=$ cash flow + cash stock), firm market-to-book value ratio $\left(M B V_{i t-1}\right)$, and lagged sales $\left(S_{i t-1}\right)$.

$$
I_{i t}=b_{1} I R E S_{i t}+b_{2} M B V_{i t-1}+b_{3} S_{i t-1}+e_{i t},
$$

$I_{i t}$ is defined as the change in the level of net fixed assets (investment) in the $i_{\text {th }}$ firm during year $t$. Investment is normalized by the level of net fixed assets to account for differences across firms. IRES it is the ratio of the sum of cash flow generated by the firm during the year and cash stock to the level of net fixed assets at the beginning of the year. Cash flow is 
calculated as the sum of net income plus depreciation, amortized intangibles, and deferred taxes, while cash stock is calculated as the sum of cash and marketable securities held at the beginning of the year. $M B V_{i t}$ ${ }_{-1}$ is a proxy for Tobin's $q$, which is the ratio of firm's market value to its book value and is an indicator of the firm's investment opportunities. Firm market value is calculated as the sum of market value of outstanding common equity and book value of long-term debt and preferred stock at the beginning of the year. Market values of equity have been calculated using stock prices at the beginning of the year. Firm book value is measured as the book value of common equity plus the book value of long term debt and preferred stock. $S_{i t-1}$ is the ratio of lagged sales to net fixed assets and is included in the model to reflect the sales accelerator theory of investment; $e_{i t}$ is the error term. The variables have been transformed into deviations from the time series mean value to adjust for fixed effects in the panel data (see Hsiao [1988]).

There should be a positive relationship between the investment ratio and the market-to-book-value ratio, since higher values for the latter indicate better financial prospects due to increased profit levels and/or a decrease in the cost of capital, both of which signify enhanced investment opportunities. Under the null hypothesis, firms have ready access to external capital, and variables measuring internal resources should not influence investment levels, i.e., $b_{1}=0$. However, under the alternate hypothesis, that lack of internal funds constrains firm investment, positive coefficients are expected for internal resources, i.e., $b_{1}>0$.

\section{B. Firm Investments and Corporate Governance Factors in Emerging Markets}

The goal of this study is to investigate how corporate governance variables influence the factors determining firm investments. Therefore, equation (1) is modified to include variables representing corporate governance factors interacting with internal resources, and market-to-book-value variables in the pooled data of firms from all of the seven countries.

$I_{i t}=b_{1} I R E S_{i t}+b_{2} M B V_{i t-1}+b_{3} S_{i t-1}+b_{4} I R E S_{i t} * I C G+b_{5} M B V_{i t-1} * I C G+e_{i t}$,

The second null hypothesis (firms have ready access to external capital) posits insignificant coefficients for internal resources and its interaction variable with the index of corporate governance, i.e., $b_{1}=0$ and $b_{4}=0$. Under the alternate hypothesis, internal resources determine 


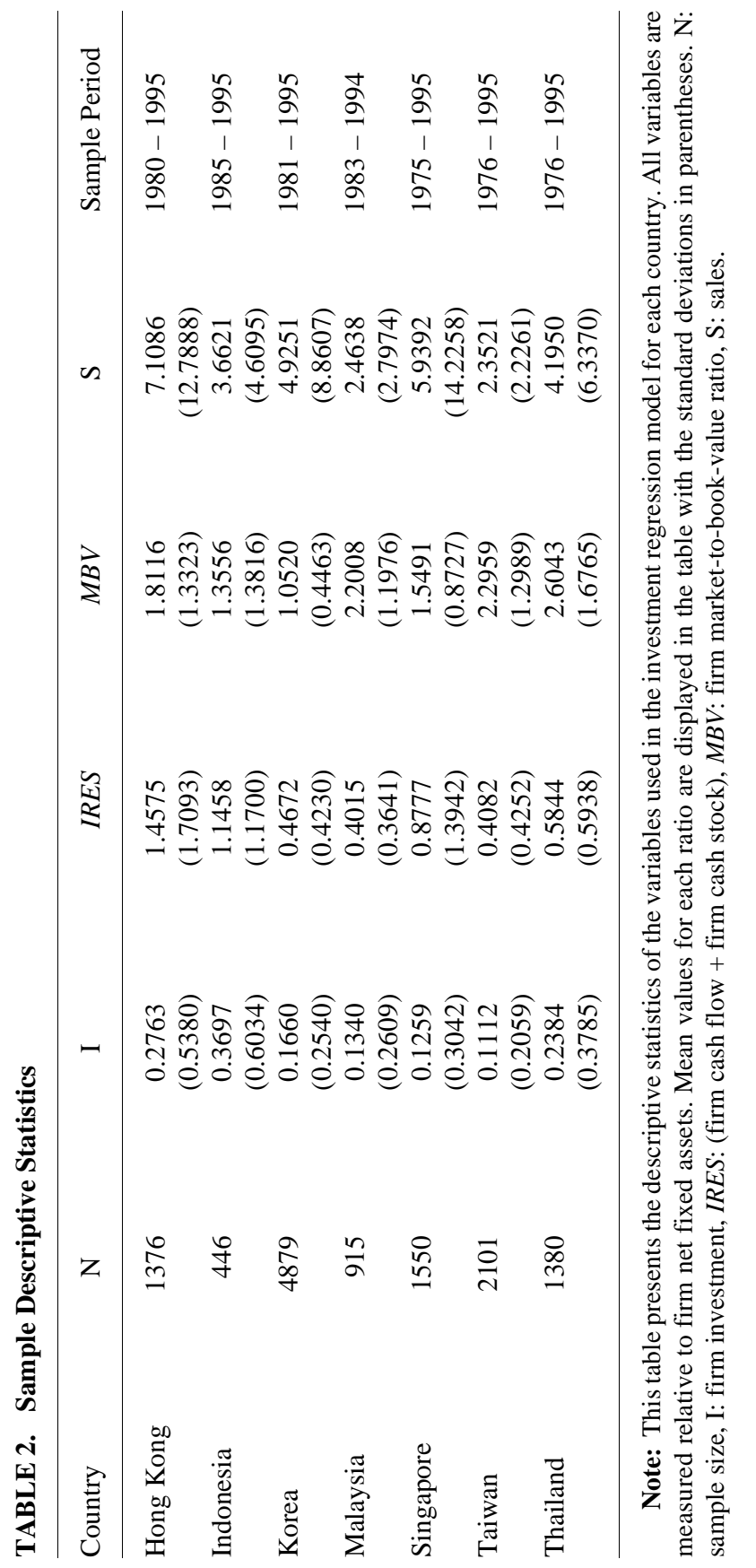


TABLE 3. Correlations of Regression Variables in the Overall Sample

\begin{tabular}{lcccc}
\hline & $\mathrm{I}$ & IRES & $M B V$ & $\mathrm{~S}$ \\
\hline $\mathrm{I}$ & 1.0000 & & & \\
IRES & 0.2729 & 1.0000 & & \\
$M B V$ & 0.1214 & 0.1100 & 1.0000 & 1.000 \\
$\mathrm{~S}$ & 0.1398 & 0.3898 & 0.0335 & \\
\hline
\end{tabular}

Note: This table presents the correlations between variables described in table 2 for the combined sample of 12,467 observations across all 7 countries included in the study. Consistent with their use in cross-sectional regressions which control for fixed effects, the variables are measured as deviations from the time-series mean for each firm. All correlations are significant at the $1 \%$ level due to the large sample size.

firm investments, i.e., $b_{1}>0$, but a good corporate governance climate diminishes its importance, i.e., $b_{4}<0$. A strong corporate governance environment enables firms to have easier access to external funds and their investments will be more closely related to the quality of available investment opportunities.

\section{Description of the Data}

The data for this study have been obtained from the PACAP databases compiled at the University of Rhode Island. Each country's sample includes firms with at least five years of data. Table 2 provides the descriptive statistics for the seven countries. ${ }^{5}$ Mean investment, as a proportion of net fixed assets $\left(I_{i t}\right)$, ranges between 0.37 (Indonesia) and 0.11 (Taiwan). The dispersion of the investment variable (standard deviation) ranges between 0.60 (Indonesia) and 0.21 (Taiwan). Mean internal resources $(I R E S=$ cash flow + cash stock), as a proportion of net fixed assets, varies between 1.46 (Hong Kong) and 0.40 (Malaysia). ${ }^{6}$ The dispersion of this variable is highest among the firms in Hong Kong (1.71) and lowest in Malaysia (0.36). Thailand registers the highest mean value of the market-to-book-value ratio $(M B V)(2.60)$, while Korea

5. The extreme values defined as the top and bottom one percent of the sample observations have been deleted for all variables. The elimination of outliers leads to more robust results.

6. Depreciation data for Hong Kong were not reported in the data base. Hence, the annual depreciation values used in the computation of net fixed assets and cash flow were imputed as follows: Buildings: 1/30; property: 1/10; vehicles: 1/15; other assets: $1 / 7$. Information obtained from other sources confirmed that straight line depreciation is the common method adopted. 
has the lowest value (1.05). The dispersion of this variable is highest among firms in Thailand (1.68) and lowest in Korea (0.45). Finally, mean lagged sales range between 7.11 (Hong Kong) and 2.35 (Taiwan).

In estimating the cross-sectional regressions, the deviations of the variables from their time-series mean for each firm are used to control for firm-specific fixed effects. Table 3 reports the correlations of the adjusted variables for the pooled dataset including observations from all 7 countries. The correlations are uniformly positive, though they are not unusually high. Nevertheless, given the large sample size of 12,647 observations, these correlations are all significant. In light of the significant correlations among the explanatory variables in the cross-sectional regressions, the condition index for each reported model is checked to ensure that multicollinearity is not a problem.

\section{Empirical Results}

In this section, the results are presented first for each country separately. Next, the impact of corporate governance is examined by including the interaction variable in the pooled sample as in equation (2). Finally, the index of corporate governance variable is replaced in the interaction variable by its components to examine their separate impacts on firm investments.

\section{A. Results for Aggregate Country Samples}

Table 4 contains the regression results for each country separately. If access to external capital markets is unconstrained, then measures of internal resources should not influence investment levels. However, the results indicate that the coefficients for internal resources are positive and significant in all countries. The coefficient for $M B V$ is significantly positive in all the countries in the sample except Indonesia (significantly negative) and Malaysia (insignificant).

The model is also re-estimated by excluding IRES and $M B V$ in turn to assess the incremental contribution of these variables. Discarding $M B V$ does not change the explanatory power of the regression in Malaysia; however, it declines in Indonesia (6\%), Hong Kong (19\%), Korea, Taiwan, and Thailand (14\%), and Singapore (50\%). When IRES is excluded, the explanatory power of the regression does not change in Singapore; however, it declines in Indonesia (56\%), Korea (75\%), 
TABLE 4. Determinants of Firm Investment from Country Data

\begin{tabular}{|c|c|c|c|c|c|c|}
\hline Country & $\mathrm{N}$ & IRES & $M B V$ & $\mathrm{~S}$ & Adj. $R^{2}$ & $F$-statistic \\
\hline \multirow[t]{3}{*}{ Hong Kong } & 1376 & $0.1179 * *$ & $0.1051 * *$ & $0.0057 * *$ & 0.1569 & $86 * *$ \\
\hline & & & $0.1245^{* *}$ & $0.0128 * *$ & 0.0885 & $68 * *$ \\
\hline & & $0.1267 * *$ & & $0.0064 * *$ & 0.1294 & $103 * *$ \\
\hline \multirow[t]{3}{*}{ Indonesia } & 446 & $0.2610 * *$ & $-0.0747 *$ & 0.0038 & 0.1603 & $29 * *$ \\
\hline & & & $-0.1088^{* *}$ & $0.0431^{* *}$ & 0.0635 & $16^{* *}$ \\
\hline & & $0.2732 * *$ & & -0.0049 & 0.1527 & $41 * *$ \\
\hline \multirow[t]{3}{*}{ Korea } & 4879 & $0.2245^{* *}$ & $0.0488 * *$ & $0.0019^{*}$ & 0.0673 & $118 * *$ \\
\hline & & & $0.0584 * *$ & $0.0077 * *$ & 0.0198 & $50 * *$ \\
\hline & & $0.2292 * *$ & & $0.0020 *$ & 0.0625 & $164 * *$ \\
\hline \multirow[t]{3}{*}{ Malaysia } & 915 & $0.3390 * *$ & 0.0141 & $0.0080^{*}$ & 0.1472 & $54 * *$ \\
\hline & & & $0.0281 * *$ & $0.0193^{* *}$ & 0.0250 & $13 * *$ \\
\hline & & $0.3446^{* *}$ & & $0.0083^{*}$ & 0.1461 & $79 * *$ \\
\hline \multirow[t]{3}{*}{ Singapore } & 1550 & $0.0366^{* *}$ & $0.0505^{* *}$ & $0.0017 *$ & 0.0338 & $19 * *$ \\
\hline & & & $0.0535^{* *}$ & $0.0031 * *$ & 0.0253 & $21 * *$ \\
\hline & & $0.0392 * *$ & & $0.0017^{*}$ & 0.0230 & $19 * *$ \\
\hline \multirow[t]{3}{*}{ Taiwan } & 2101 & $0.1041^{* *}$ & $0.0138 * *$ & $0.0182 * *$ & 0.0658 & $50 * *$ \\
\hline & & & $0.0196^{* *}$ & $0.0284 * *$ & 0.0463 & $52 * *$ \\
\hline & & $0.1170 * *$ & & $0.0173^{* *}$ & 0.0604 & $68 * *$ \\
\hline \multirow[t]{3}{*}{ Thailand } & 1380 & $0.2371 * *$ & $0.0383 * *$ & $0.0090 * *$ & 0.1373 & $74 * *$ \\
\hline & & & $0.0586^{* *}$ & $0.0173 * *$ & 0.0755 & $57 * *$ \\
\hline & & $0.2712 * *$ & & $0.0078 * *$ & 0.1210 & $96 * *$ \\
\hline
\end{tabular}

Note: This table presents the regression results for the aggregate sample from each country. The dependent variable is investment $(I)$ measured as change in the level of net fixed assets. The independent variables are IRES: (cash flow + cash stock), $M B V$ : market-to-book-value ratio, and $\mathrm{S}$ : sales. $N$ is sample size, ${ }^{*}$ and $* *$ represent statistical significance at 5 and $1 \%$ levels, respectively.

Malaysia (80\%), Taiwan (29\%), Thailand (43\%), and Hong Kong $(44 \%)$. Therefore, the internal resources variable has independent explanatory power and reflects effects not captured by the other independent variables in at least these six countries. Consistent with research proposition 1 , the results indicate that, while firm investments are responsive to market assessments of profitability, internal resources are an important determinant of firm investments in these countries. ${ }^{7}$

7. In emerging markets, other factors, such as political connections and firm reputation, enable firms to access sources of financing for their investment projects. Well-established, reputed firms with good analyst coverage may have better access to capital markets and, hence, their investments may be less dependent on internal resources. Firm age is a useful proxy for firm reputation. However, the returns to age in the form of firm reputation are likely to decay over time and hence the nature of the relation should be essentially non-linear and therefore, $\log$ (firm age) was included in the regression model. The explanatory power of the model remains unchanged and in the interest of conserving space these results are not included in table 4 . 
TABLE 5. Determinants of Firm Investments from Pooled Country Data

\begin{tabular}{lcccc}
\hline Variable & 1 & 2 & 3 & 4 \\
\hline$I R E S$ & $0.1301^{* *}$ & $0.4000^{* *}$ & $0.1291^{* *}$ & $0.4065^{* *}$ \\
$M B V$ & $0.0368^{* *}$ & $0.0343^{* *}$ & -0.0204 & $-0.0374^{*}$ \\
$\mathrm{~S}$ & $0.0024^{* *}$ & $0.0028^{* *}$ & $0.0023^{* *}$ & $0.0027^{* *}$ \\
$I R E S^{*} I C G$ & & $-0.0048^{* *}$ & & $-0.0050^{* *}$ \\
$M B V^{*} I C G$ & & & $0.0013^{* *}$ & $0.0016^{* *}$ \\
Adj. $R^{2}$ & 0.0841 & 0.0988 & 0.0854 & 0.1009 \\
$F-$ statistic & $388^{* *}$ & $348^{* *}$ & $296^{* *}$ & $285^{* *}$ \\
$N$ & 12647 & 12647 & 12647 & 12647 \\
\hline
\end{tabular}

Note: This table presents the regression results for the pooled data from all countries for various specification of the basic model. The dependent variable is investment $(I)$ measured as change in the level of net fixed assets. The independent variables are IRES: (cash flow + cash stock), $M B V$ : market-to-book-value ratio, and S: sales. Interaction variables IRES*ICG and $M B V^{*} I C G$ have been included in some models to measure how ICG influences the impacts of IRES and $M B V$ on firm investment. $N$ is sample size, * and ** represent statistical significance at 5 and $1 \%$ levels, respectively.

\section{B.Results for the Pooled Data}

Table 5 presents the regression results for the pooled data from all the countries in our sample. In addition to the variables used in the individual country regressions, variables obtained by separately interacting $I C G$ with IRES and $M B V$ are included. The first specification estimates the basic model used in the individual country regressions. All three independent variables, IRES, $M B V$, and $S$, are positive and significant at the one per cent level, supporting research proposition 1 . These results are similar to those obtained for the individual countries in table 4, except for the results for Indonesia (significantly negative coefficient for $(M B V)$ and Malaysia (insignificant coefficient for $M B V$ ). Thus, the pooled country data yield similar results as the individual country data.

The second specification includes an additional variable obtained by interacting IRES and ICG. While the coefficients for the first three variables (IRES, $M B V, S)$ are significant and positive, the coefficient for the interactive variable is significant and negative. This is a key result which supports research proposition 2. Specifically, the negative coefficient of the interaction term indicates that while firm investments are influenced by the level of internal resources, the dependence of firm investments on internal resources diminishes with improvements in the corporate governance climate.

The third specification substitutes the interaction variable in the 


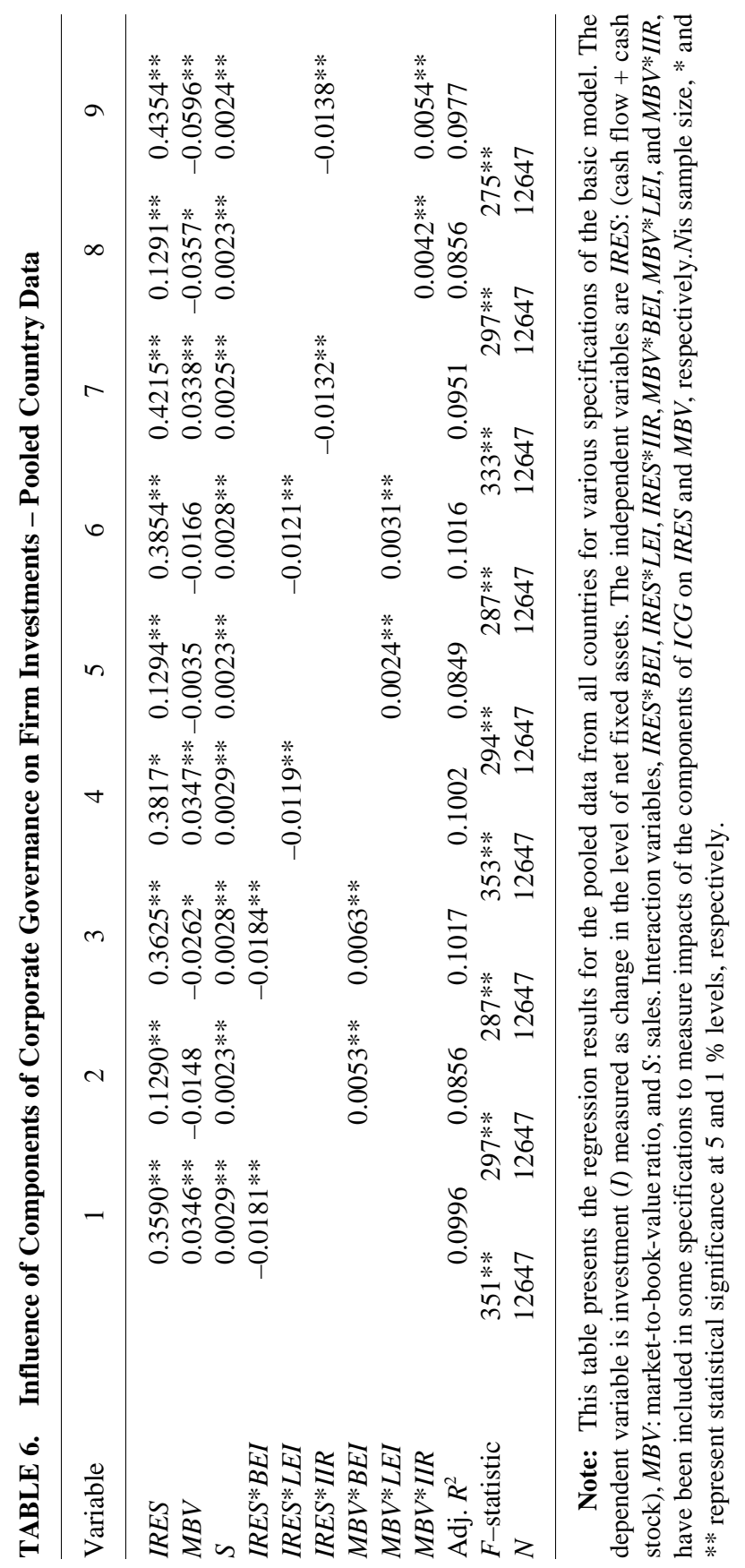


second specification by interacting $M B V$ with $I C G$. The coefficients for IRES and $S$ are significant and positive. However, the coefficient for $M B V$ is insignificant and the coefficient for the interactive term is significant and positive. The interpretation of this result is that, while investment opportunities do not influence firm investments in the pooled data, the introduction of corporate governance enhances the impact of investment opportunities on firm investment. Finally, the fourth specification includes both interaction variables used in the second and third models. All of the independent variables are significant; however, $M B V$ and $I R E S^{*} I C G$ have negative coefficients. This result implies that, while firm investments in the pooled sample are determined by internal resources, sound corporate governance diminishes the importance of internal resources on firm investments. Furthermore, corporate governance enhances the impact of investment opportunities on the firm's investments. Thus the overarching conclusion from table 5 is that good corporate governance diminishes the need for the firm to rely on its internal resources to finance its investments. Furthermore, good corporate governance promotes firm investments solely on the objective criterion of the quality of the firm's opportunities.

While the results are consistent with a significant influence of the corporate governance regime on firm investment decisions, the results presented here may also capture other cross-country differences. If these cross-country differences are correlated with both corporate governance regimes and investment, then their omission from the model may give rise to spurious estimates of the role of corporate governance.

\section{The Effects of the Components of Corporate Governance}

The previous results are extended by considering the influence on firm investments of the components of corporate governance: business environment index $(B E I)$, legal environment index $(L E I)$, and index of investor rights $(I I R)$. Table 6 presents the regression results for the pooled data with $B E I, L E I$, and IIR replacing ICG sequentially in the interaction variables. Thus, specifications 1,4 , and 7 in table 6 correspond to specification 2 in table 5, with BEI, LEI, and IIR, respectively, replacing $I C G$ in the interactive term. Specifications 2, 5 and 8 in table 6 derive from specification 3 in table 5, with BEI, LEI and $I I R$, respectively, replacing $I C G$ in the interactive terms. Finally, specifications 3, 6 and 9 in table 6 correspond to specification 4 in table 5 , with $B E I, L E I$, and $I I R$, respectively, replacing $I C G$ in the interactive variable. The results in table 6 are quite consistent with the results 
reported in table 5. For example, when $I C G$ is replaced by each of its three components, the interaction term with IRES is significantly negative (specifications 1,4 , and 7). Similarly, the interaction term with $M B V$ is significantly positive in specifications 2,5 , and 8 . Finally, the interaction term with IRES is significantly negative and the interactive term with $M B V$ is significantly positive in specifications 3, 6, and 9. The results in table 6 imply that, while the firm's internal resources influence firm investments in the sample, improving the business and legal environments and enhancing investor rights result in diminishing the reliance of firm investments on internal resources. ${ }^{8}$ Furthermore, improvements in the business and legal environments and enhancement of investor rights result in firm investments being made strictly on the objective criterion of the quality of its opportunities.

While the results do not identify the legal environment as the dominant component leading to good corporate governance, they suggest that it is essential for good investor protection. A good legal system provides the basis for the contractual and fiduciary responsibilities that firms offer their investors. Enforcement of a good legal system ensures that the costs imposed by corruption are minimized and firms are valued strictly on the basis of the financial benefits they provide to their investors.

\section{Conclusion}

This paper examines the association between corporate governance standards and the determinants of firm investments for a sample of Asian emerging markets. Changes in firm investments are sensitive to changes in internal resources in all the countries in the sample. This result suggests that corporate investments are constrained by internal liquidity. Further analyses reveal that good corporate governance regimes mitigate the dependency of firm investments on its internal resources and strengthen its relationship with the firm's investment opportunities.

With increased confidence in the corporate governance environment, firms are less constrained by their internal resources in financing their investments, as they have access to market-based sources of funding.

8. These results should be interpreted with caution since the components of the corporate governance are highly correlated with each other. A model which includes all three of the components suffers from severe multicollinearity as judged by the condition index test. 
The broad conclusion is that, where corporate governance ensures the protection of minority shareholders, external capital will be forthcoming to meet the capital budgeting needs of firms based on profitability of investments. On the other hand, where corporate governance does not provide for the protection of minority shareholders, firms will have to rely on their internal resources.

These findings have broad implications. Since the 1980s, many countries have increasingly liberalized their economies and turned to market-oriented decision systems. In a globalized economy, the public corporation provides an efficient and competitive organizational form to conduct business. The viability of this organizational form hinges crucially on the protection of investor rights, as seen by concerns voiced in the wake of the Enron debacle. Countries that protect shareholder rights experience increases in corporate values and in the number of listed firms (LaPorta et al. [2000]). This study provides additional supporting evidence that investor protection facilitates improved access to external capital and enables individual firms to undertake more value-maximizing investments. Thus, developing and emerging economies, in particular, would find it economically beneficial to develop corporate governance environments that encourage the protection of investor rights through improvements in the quality of the legal system.

\section{Appendix: Description of Corporate Governance Variables}

Definitions for the variables measuring the corporate governance environment are presented here. Several of these definitions are from LaPorta et al. (1998). The definition of Minority Shareholder Rights has been extracted from Johnson et al. (2000). Values for the corporate governance variables are presented in table 1.

Corruption: Source: International Country Risk (ICR-country risk rating agency). This measure is ICR's assessment of corruption in the government. Lower scores indicate that "high government officials are likely to demand special payments" and "illegal payments are generally expected throughout lower levels of government" in the form of "bribes connected with import and export licenses, exchange controls, tax assessment, policy protection and loans." Average of values obtained in the period 1982 - 1995. Values are scaled between 0 and 10, with lower scores implying higher levels of corruption.

Transparency: Source: Chart 1, The Economist (4.7.01), "Survey of Asian Business," p. 4. The values in the original chart were inversely related to the level of transparency. These values are re-mapped so that they are directly related to the level of transparency.

Business Environment Index (BEI): This index sums up scores for corruption 
and transparency.

Judicial Efficiency: Source: Business International Corporation (BIC- country risk rating agency). "Efficiency and integrity of the legal environment as it affects business, particularly foreign firms." It "may be taken to represent investors' assessments of conditions in the country in question." Average of values obtained in the period $1980-1983$. Values are scaled between 0 and 10, with lower scores implying lower efficiency levels.

Rule of Law: Source: ICR. This measure is an assessment of law and order tradition in the country. Average of values obtained in the months of April and October of the monthly index obtained in the period $1982-1995$. Values are scaled between 0 and 10, with lower scores implying less tradition for law and order.

Quality of Legal System: Source: Chart 7, The Economist (4.7.01), "Survey of Asian Business," p. 16. The values in the original chart were inversely related to the quality of the legal system. These values are re-mapped so that they are directly related to the quality of the legal system.

Legal Environment Index ( $L E I)$ : This index is constructed by summing up scores for judicial efficiency, rule of law and quality of the legal system.

Minority Shareholder Rights: Source: Flemings Research. This measure is an alternative measure of corporate governance which "tries to capture the extent of shareholder rights in practice." It considers "the disclosure of information, transparency of ownership structures, management and special interest groups, adequacy of the legal system, whether the standards that are set are actually enforced, and if the boards of companies are independent and the rights of minority shareholders are upheld." Values are scaled between 1 and 5, with lower scores implying less shareholder rights. The values are re-scaled between 0 and 10 to ensure consistency among the measures.

Anti-director Rights: LaPorta et al. (1998) create this index by aggregating shareholder rights. The authors form this index by "adding 1 when (i) the country allows shareholders to mail their proxy form to the firm, (ii) shareholders are not required to deposit their shares prior to the general shareholders' meeting, (iii) cumulative voting or proportional representation in the board of directors is allowed, (iv) an oppressed minorities mechanism is in place, ( $v$ ) the minimum percentage of share capital that entitles a shareholder to call for an extraordinary shareholders' meeting is less than or equal to 10 percent (the sample median), or (vi) shareholders have preemptive rights that can be waived only by a shareholder's vote." Values of the index range between 1 and 6 . The values are re-scaled between 0 and 10 to ensure consistency among the measures.

Creditor Rights: LaPorta et al. (1998) form this index by aggregating different creditor rights. "The index is formed by adding 1 when (1) the country imposes restrictions, such as creditors' consent or minimum dividends to file for reorganization; (2) secured creditors are able to gain possession of their security once the reorganization petition has been approved (no automatic 
stay); (3) secured creditors are ranked first in the distribution of the proceeds that result from the disposition of assets of a bankrupt firm; and (4) the debtor does not retain the administration of its property pending the resolution of the reorganization." Their index ranges from 0 to 4 ; it is re-scaled it so that the maximum value is 10 .

Index of Investor Rights (IIR): This index adds the scores for minority shareholder rights, anti-director rights and creditor rights.

Index of Corporate Governance (ICG): This index is constructed for each country by aggregating its $B E I, L E I$, and $I I R$ scores. Thus, the magnitude of the value of this index for a country is directly related to the quality of corporate governance available in that country.

Quality of Corporate Governance $(Q C G)$ : Source: Chart 1, The Economist (4.7.01), "Survey of Asian Business," p. 4. The values in the original chart were inversely related to the quality of corporate governance. These values are re-mapped so that they are directly related to the quality of corporate governance.

\section{References}

Athey, M. J., and Laumas, P. 1994. Internal funds and corporate funds in India. Journal of Development Economics 45:287-303.

Beck, T.; Levine, R.; and Loayza, N. 2000. Finance and sources of growth. Journal of Financial Economics 58:261-300.

Cho, M-H. 1998. Ownership structure, investment and the corporate value: An empirical analysis. Journal of Financial Economics 47:103-121.

Demsetz, H., and Lehn, K. H. 1985. The structure of corporate ownership: Causes and consequences. Journal of Political Economy 93: 1155-77.

Devereux, M., and Schiantarelli, F. 1990. Investment, financial factors, and cash flow: Evidence from UK panel data, in Hubbard, R. G., (Ed.), Asymmetric Information, Corporate Finance, and Investment (University of Chicago Press and NBER):279-306.

Errunza, V. 2001. Foreign portfolio equity investments, financial liberalization, and economic development. Review of International Economics 9: 703-726.

Fazzari, S. M.; Hubbard, R. G.; and Petersen, B. C. 1988. Financing constraints and corporate investment. Brookings Papers on Economic Activity I: 141-95.

Hoshi, T.; Kashyap, A.; and Scharfstein, D. 1991. Corporate structure, liquidity and investment: Evidence from Japanese panel data. Quarterly Journal of Economics 106: 33-60.

Hsiao, C. 1988. Analysis of Panel Data. Cambridge University Press.

Jensen, M. C., and Meckling, W. H. 1976. The theory of the firm: Managerial behavior, agency costs and ownership structure. Journal of Financial Economics 3: 305-360.

Johnson, S.; Boone, P.; Breach, A; and Friedman, E. 2000. Corporate 
governance in the Asian financial crisis. Journal of Financial Economics 58: 141-186.

Kadapakkam, P; Kumar, P. C.; and Riddick, L. 1998. The impact of cash flows and firm size on investment: The international evidence. Journal of Banking and Finance 22: 293-320.

Kaplan, S., and Zingales, L. 1997. Do investment-cashflow sensitivities provide useful measures of financing constraints? Quarterly Journal of Economics 112: $169-215$.

Karmin, C. 2000. Corporate-governance issues hamper emerging markets. Wall Street Journal, November 11.

LaPorta, R.; Lopez-de-Silanes, F.; Shleifer, A.; and Vishny, R. W. 1997. Legal determinants of external finance. Journal of Finance 52: 1131-1150.

LaPorta, R.; Lopez-de-Silanes, F.; Shleifer, A.; and Vishny, R. W. 1998. Law and finance. Journal of Political Economy 106: 1113-1155.

LaPorta, R.; Lopez-de-Silanes, F.; Shleifer, A.; and Vishny, R. W. 2000. Investor protection and corporate governance. Journal of Financial Economics 58:3-27.

McConnell, J. J., and Servaes, H., 1990. Additional evidence on equity ownership and corporate value. Journal of Financial Economics 27: 595-612.

Morck, R.; Shleifer, A.; and Vishny, R. W. 1988. Management ownership and market valuation: An empirical analysis. Journal of Financial Economics 20: $293-315$.

Myers, S.C., and Majluf, N. S. 1984. Corporate financing and investment decisions when firms have information that investors do not have. Journal of Financial Economics 13: 187-221.

Schaller, H. 1993. Asymmetric information, liquidity constraints, and Canadian investment. Canadian Journal of Economics 36: 552-74.

Shleifer, A., and Vishny, R. W. 1997. A survey of corporate governance. Journal of Finance 52: 737-783.

Vogt, S. C. 1994. The Cash flow/investment relationship: Evidence from U.S. manufacturing firms. Financial Management 23:3-20. 